\title{
Neurology
}

\section{An Isolated Unilateral Hypoglossal Nerve Palsy Due to a Base of Skull}

\section{Meningioma}

Jessica Coenen, MBChB, BSc (hons) ${ }^{1}$; Jonathan Cleaver, BSc (hons), MBChB (hons) ${ }^{2}$; Richard James, $\mathrm{MBChB}^{3}$; Gurjit Chohan, $\mathrm{MBChB}^{2}$

\section{Corresponding Author:}

Jessica Coenen

jessica.coenen@nhs.net

1. Gastroenterology, Imperial College Healthcare NHS Trust, London, UK;

2. Department of Neurology, Royal United Hospital Bath NHS Trust, Bath, UK;

3. Neuroradiology, Royal United Hospital Bath NHS Trust, Bath, UK

Neurology ${ }^{\circledR}$ Published Ahead of Print articles have been peer reviewed and accepted for publication. This manuscript will be published in its final form after copyediting, page composition, and review of proofs. Errors that could affect the content may be corrected during these processes. 


\section{Contributions:}

Jessica Coenen: Drafting/revision of the manuscript for content, including medical writing for content

Jonathan Cleaver: Drafting/revision of the manuscript for content, including medical writing for content

Richard James: Analysis or interpretation of data

Gurjit Chohan: Major role in the acquisition of data

Number of characters in title: 81

Word count of main text: 100

References: 2

Figures: 2

Tables: 0

Neuroimage Legend Count: 190

Supplemental: Patient consent form; Figure 1 Figure 2 Teaching Slide Deck

Search Terms: [ 15 ] Clinical neurology history, [ 16 ] Clinical neurology examination, [119] CT, [ 120 ] MRI

\section{Study Funding:}

The authors report no targeted funding

\section{Disclosure:}

The authors report no disclosures relevant to the manuscript. 
A 73-year-old lady presented with a 6-month history of intermittent lisp, drooling and aspiration. Initial assessment showed right hemi-tongue atrophy (Figure 1) with ipsilateral fasciculations and weakness. Residual neurological examination was unremarkable. MRI-brain confirmed a right hypoglossal nerve palsy (HNP) secondary to a hypoglossal canal meningioma, with classical radiological appearances (Figure 2).

Isolated HNP is rare and often heralds metastatic disease or is idiopathic [1,2]. Other causes include local arteriovenous fistulae, Chiari malformations and iatrogenic from posterior fossa surgery or carotid endarterectomy[2]. Benign meningiomas rarely cause an isolated HNP but typical radiological appearances illustrated can confirm diagnosis and avoid biopsy.

Teaching Slides - http://links.Iww.com/WNL/B428

\section{References}

1. Khoo, S., Ullah, I., Wallis, F., \& Fenton, J. (2007). Isolated hypoglossal nerve palsy: A harbinger of malignancy. The Journal of Laryngology \& Otology, 121(8), 803-805. doi:10.1017/S0022215107006275

2. Keane JR. Twelfth-nerve palsy. Analysis of 100 cases. Arch Neurol. 1996;53(6):561 $\square 566$. doi:10.1001/archneur.1996.00550060105023 
Figure 1 Clinical sign versus image depiction of hypoglossal nerve palsy - A)

Photograph of the patient demonstrating right tongue deviation and atrophy. B) Coronal FLAIR MRI 2016 - Abnormal signal hyperintensity in the right hemi-tongue representing fatty infiltration as a consequence of right CN XII compromise (red arrow).

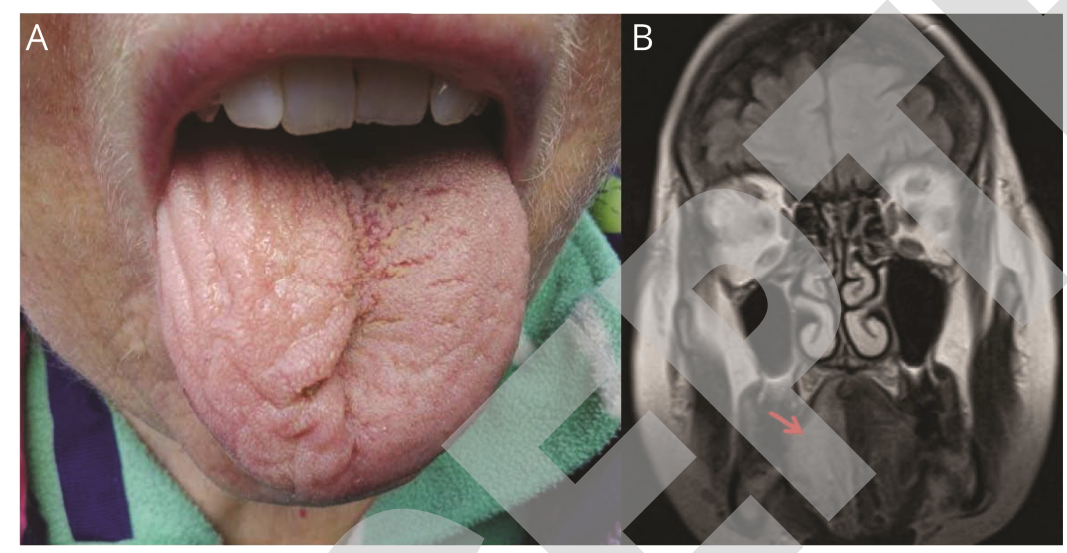

Figure 2 Interval MR scanning showing progression of meningioma- A). Axial T2 MRI 2016 - Abnormal mildly T2 hyperintense soft tissue within the right inferior foramen magnum (red arrow) and extending into the hypoglossal canal (Dotted arrow). Highlighted surrounding structures include the right internal carotid artery (yellow), right internal jugular vein (green) and right vertebral artery (blue). B \& C). 3-year follow up MRI. Axial and Coronal T1 SPACE post-contrast MRI respectively - Interval increase in size of the right foramen magnum and hypoglossal canal meningioma which now abuts the inferior medulla and upper cervical spinal cord (red arrow) Right vertebral artery shown in blue. D) Reformatted Coronal intracranial CT - Angiogram (bone kernel) 
demonstrates subtle right bony hyperostosis within the right foramen magnum at the hypoglossal canal orifice; a classical finding in a meningioma. Aneurysmal aetiology was excluded in this study (not shown).

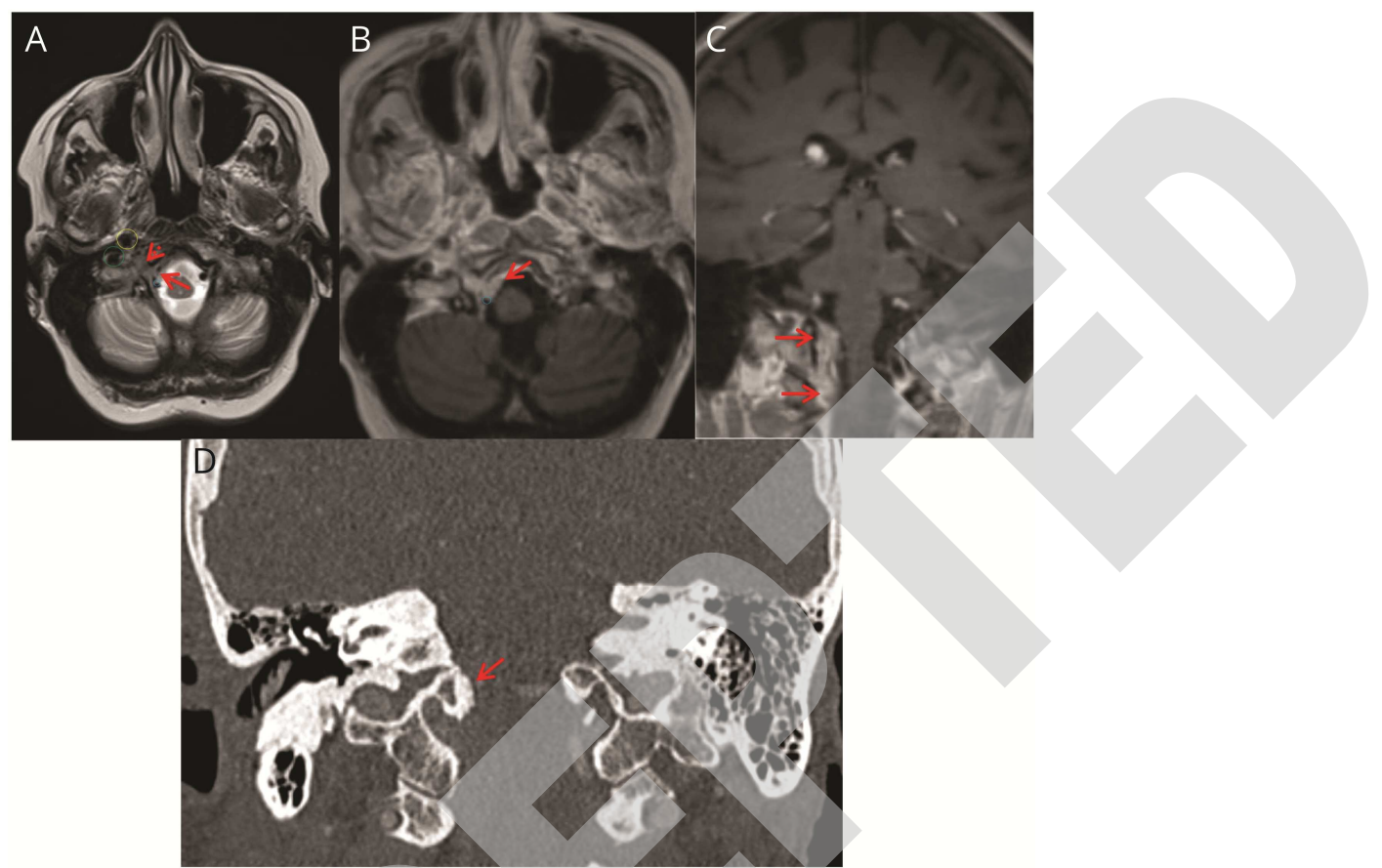




\title{
Neurology
}

\author{
An Isolated Unilateral Hypoglossal Nerve Palsy Due to a Base of Skull Meningioma \\ Jessica Coenen, Jonathan Cleaver, Richard James, et al. \\ Neurology published online May 24, 2021 \\ DOI 10.1212/WNL.0000000000012232
}

\section{This information is current as of May 24, 2021}

\section{Updated Information \& Services}

Subspecialty Collections

Permissions \& Licensing

Reprints including high resolution figures, can be found at:

http://n.neurology.org/content/early/2021/05/24/WNL.0000000000012232. citation.full

This article, along with others on similar topics, appears in the following collection(s):

Clinical neurology examination

http://n.neurology.org/cgi/collection/clinical_neurology_examination Clinical neurology history

http://n.neurology.org/cgi/collection/clinical_neurology_history

CT

http://n.neurology.org/cgi/collection/ct

MRI

http://n.neurology.org/cgi/collection/mri

Information about reproducing this article in parts (figures,tables) or in its entirety can be found online at:

http://www.neurology.org/about/about_the_journal\#permissions

Information about ordering reprints can be found online:

http://n.neurology.org/subscribers/advertise

Neurology ${ }^{\circledR}$ is the official journal of the American Academy of Neurology. Published continuously since 1951, it is now a weekly with 48 issues per year. Copyright (C) 2021 American Academy of Neurology. All rights reserved. Print ISSN: 0028-3878. Online ISSN: 1526-632X.

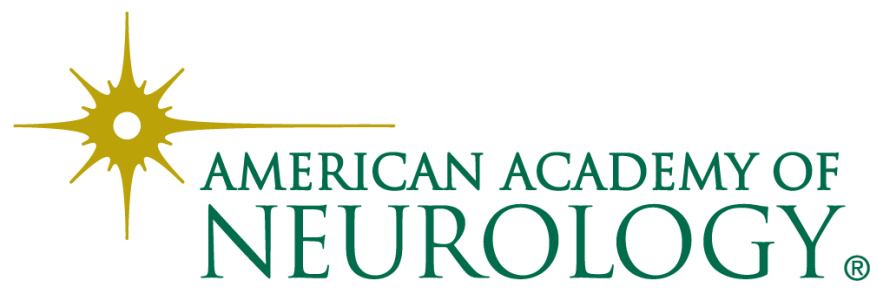

